\title{
Intellectual structure of Library and Information Science in Iberoamerica using journal co-citation analysis: a comparative study based on Scopus and Web of Science
}

\author{
Estrutura intelectual da Biblioteconomia e Ciência da Informação \\ na Iberoamérica usando análise de co-citação de periódicos: um \\ estudo comparativo baseado em Scopus e Web of Science
}

\author{
Carlos Luis GONZÁLEZ-VALIENTE1 (id) 0000-0002-1836-5257 \\ Evony Katherine LÓPEZ-MESA² (D) 0000-0001-9148-4001
}

\begin{abstract}
In this study, the intellectual structure of the Iberoamerican research on Library and Information Science was visualized, from the perspective of journal citation relations. In addition, the core journals that most influence intellectual structure were identified. The study had a comparative emphasis since data from Scopus and Web of Science Core Collection were used. Journal cocitation maps were generated to identify the journal communities. Strategic diagrams with citation and betweenness centrality measures were also generated to identify core, under development, and peripheral journals. The results showed that the intellectual structure is fragmented into communities that respond to the geographic context and language affinity. Only two journals are considered core, El Profesional de la Información and Ciência da Informação. In general, there was not much difference in the comparative analyzes between the two databases. Complementary studies are necessary to show which epistemic factors influence the current fragmentation of the intellectual structure of the Library and Information Science research in the region.
\end{abstract}

Keywords: Iberoamerican research. Intellectual structure. Journal co-citation analysis. Library and information science. Science mapping.

\section{Resumo}

Neste estudo, foi visualizada a estrutura intelectual da pesquisa em Biblioteconomia e Ciência da Informação na América Latina, sob a ótica das citações de periódicos. Além disso, foram identificados os principais periódicos que mais influenciam a estrutura intelectual. O estudo teve uma ênfase comparativa, uma vez que foram usados dados da Scopus e da Web of Science Core Collection. Mapas de cocitação de revistas foram elaborados e permitiram a identificação das comunidades de revistas. Diagramas estratégicos com medidas de citação e centralidade de intermediação também foram gerados para identificar periódicos centrais, em desenvolvimento e periféricos. Os resultados mostraram que a estrutura intelectual está fragmentada em comunidades que respondem ao contexto geográfico e à afinidade linguística. Apenas duas revistas são consideradas centrais: El Profesional de la Información e Ciência da

1 European Alliance for Innovation, Publications Department. Vazovova 3, 811 07, Bratislava, Slovakia. Correspondência para/Correspondence to: C. L. GONZÁLEZ-VALIENTE. E-mail: <carlos.valiente89@gmail.com>.

2 Biblioteca Universidad La Gran Colombia, Coordinación de Servicios al Usuario. Bogotá, Colombia.

Received on May 14, 2021, final version resubmitted on August 25, 2021 and approved on October 10, 2021.

Como citar este artigo/How to cite this article

González-Valiente, C. L.; López-Mesa, E. K. Intellectual structure of Library and Information Science in Iberoamerica using journal co-citation analysis: a comparative study based on Scopus and Web of Science. Transinformação, v. 34, e210036, 2020. https://doi.org/10.1590/2318-0889202234e210036 
Informação. Em geral, não houve muita diferença nas análises comparativas entre as duas bases de dados. Estudos complementares são necessários para mostrar quais fatores epistêmicos influenciam a atual fragmentação da estrutura intelectual da Biblioteconomia e Ciência da Informação na região ibero-americana.

Palavras-chave: Pesquisa Ibero-americana. Estrutura intelectual. Análise de co-citação de periódicos. Biblioteconomia e ciência da informação. Mapeamento de ciência.

\section{Introduction}

The 'information sciences' in Ibero-America, understood as the knowledge space that brings together library science, information science, archival science, and museology, has reached high levels of disciplinary development. Despite being highly influenced by North American and European concepts and theories, it has evolved with unique identity traits (Araújo; González-Valiente, 2019).

Ibero-America is a regional context characterized by common historical, cultural, social, and economic traditions, regardless of the linguistic factor, which also influences its scientific production scheme. It is on this generic premise that Araújo (2018a) proposes the possible existence of an 'Ibero-American informational thinking', given the cooperation initiatives that over time have been strengthened among the countries of the region. Araújo (2018b) mentions initiatives such as the holding of regional events starting in 1993, the formalization in 1996 of the Association for Education and Research in Information Science of Ibero-America and the Caribbean (EDICIC in Spanish, formerly EDIBCIC), as well as the orientation towards the study and research of similar thematic lines.

The benefits provided by bibliometric methods and techniques have made it possible to identify and visualize several dimensions of the structure, evolution, and particular traits of IS in Ibero-America. Although, most of these studies have been reduced to a national scope, as evidenced in the cases of Brazil (Araújo; Valentim, 2019; Liberatore; Herrero-Solana, 2013), Spain (Abadal; Guallar, 2020), Portugal (Borges, Freitas; Oliveira, 2019; Oliveira et al., 2017), Cuba (Amaro-Ares, Vega-Almeida; Arencibia-Jorge, 2018; Mugica, Columbié; Salomón, 2019; Vega-Almeida; Arencibia-Jorge, 2021), Mexico (Herrera-Miranda, Arenas; Gómez-Hernández, 2013; Morán-Reyes, 2021), Colombia (Jaramillo; Morillo, 2019), Uruguay (Sabelli, 2019), and Argentina (Corda; Liberatore, 2021). Studies with a Latin/Ibero-American scope have revealed interesting findings such as:

- Inbreeding relationships between journals and countries in the region (Gorbea-Portal; Suárez-Balseiro, 2007);

- A limited number of journals concentrate the greatest citations impact, highlighting the ones from Spain and Brazil (Herrero-Solana; Liberatore, 2008);

- High prevalence of national collaborations, while visibility in first quartile journals is mainly conditioned by the collaboration with authors from North American and European countries (Sánchez-Perdomo et al., 2017);

- Increase in the number of publications indexed in Web of Science (WOS), highlighting the scientific production of Spain, Brazil and Mexico (Vergara-Vera et al., 2020), and

- An increase in the number of English-language publications, as well as strong collaborative relationships between Brazil, Spain, Mexico and Cuba (Gutiérrez, 2020).

A recent study published by González-Valiente (2019) distinguished the internal relationships of the scientific structure of IS in Ibero-America during the period 1996-2017, using co-citation analysis of 20 journals indexed in Scopus. The results revealed a disciplinary fragmentation of the IS field, which seems to be influenced by the language and geographic origin of the journals. For this reason, this article will delve into the intellectual structure of Ibero-American research on IS considering a broader temporal coverage and data source than those previously used by González-Valiente (2019). Thus, the purpose of this study is to visualize the intellectual structure of the Ibero-American research on IS, but from a comparative perspective applying co-citation analysis of journals indexed 
in Scopus and Web of Science Core Collection (WoS-CC). Across this paper, the following Research Questions (RQ) will be answered:

RQ 1: What is the intellectual structure of the Ibero-American research on IS from the perspective of co-citation networks of journals indexed in Scopus and WoS-CC?

$\mathrm{RQ} 2$ : What are the core journals in the intellectual structure of the Ibero-American research on IS, according to Scopus and WoS-CC?

\section{Methodological Procedures}

Given the comparative character of this study, two data sources were considered, Scopus and WoS-CC. Both databases were selected given the availability to export cited reference metadata for bibliometric purposes. The analysis was performed using journals at the aggregation level. To select the journals, we made a manual revision of all the journal titles listed in the category 'Library and Information Science' in Scopus, and 'Information Science \& Library Science' in WoS, and whose publisher address was an Ibero-American country. By this procedure, we identified a total of 33 source journals (Table 1), out of which 17 titles were covered in both databases. When removing overlap, we found 8 titles indexed in WoS-CC not covered in Scopus, while the same number of journals

(8) were in Scopus, but not in WoS-CC.

Table 1 - List of source journals.

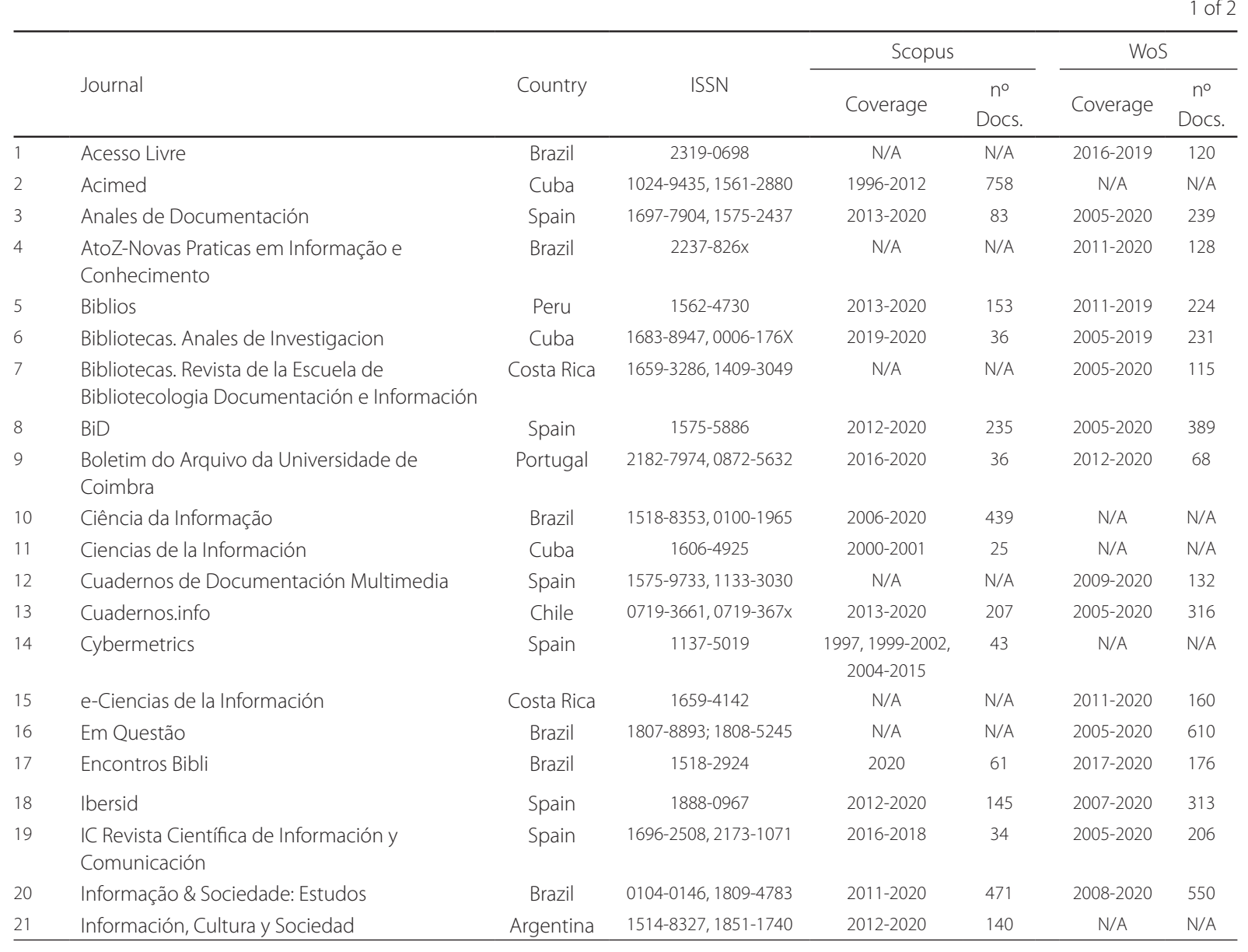


Table 1 - List of source journals.

\begin{tabular}{|c|c|c|c|c|c|c|c|}
\hline & & & & Scopi & & Wos & \\
\hline & Journal & Country & ISSN & Coverage & $\begin{array}{c}n^{\circ} \\
\text { Docs. }\end{array}$ & Coverage & $\begin{array}{c}n^{\circ} \\
\text { Docs. }\end{array}$ \\
\hline 22 & Investigación Bibliotecológica & Mexico & $0187-358 X$ & $2008-2020$ & 408 & $2007-2020$ & 394 \\
\hline 23 & Metodos de Información & Spain & $1134-2838,2173-1241$ & N/A & N/A & $2010-2020$ & 111 \\
\hline 24 & Perspectivas em Ciência da Informação & Brazil & $1413-9936,1981-5344$ & $2008-2020$ & 628 & $2005-2020$ & 622 \\
\hline 25 & Profesional de la Información & Spain & $1386-6710,1699-2407$ & $2006-2020$ & 1447 & $2006-2020$ & 1361 \\
\hline 26 & $\begin{array}{l}\text { Revista Cubana de Información en Ciencias de } \\
\text { la Salud }\end{array}$ & Cuba & $2307-2113$ & 2013-2020 & 242 & N/A & N/A \\
\hline 27 & $\begin{array}{l}\text { Revista Digital de Biblioteconomia e Ciência da } \\
\text { Informação }\end{array}$ & Brazil & $1678-765 X$ & 2018-2020 & 117 & N/A & N/A \\
\hline 28 & Revista Española de Documentación Cientifica & Spain & $0210-0614,1988-4621$ & $2008-2020$ & 407 & $2008-2020$ & 396 \\
\hline 29 & $\begin{array}{l}\text { Revista General de Información y } \\
\text { Documentación }\end{array}$ & Spain & $1132-1873,1988-2858$ & $2009-2020$ & 257 & $2005-2020$ & 359 \\
\hline 30 & $\begin{array}{l}\text { Revista Ibero-Americana de Ciência da } \\
\text { Informação }\end{array}$ & Brazil & 1983-5213 & N/A & N/A & $2008-2020$ & 269 \\
\hline 31 & Revista Interamericana de Bibliotecologia & Colombia & 0120-0976, 2538-9866 & $2000-2020$ & 348 & N/A & N/A \\
\hline 32 & Scire & Spain & $1135-3716$ & $2011-2020$ & 179 & $2005-2020$ & 282 \\
\hline 33 & TransInformação & Brazil & 0103-3786 & $2010-2020$ & 270 & $2008-2020$ & 311 \\
\hline To & & & & & 7169 & & 8082 \\
\hline
\end{tabular}

Note: ISSN: International Standard Serial Number; N/A: Not Available; WoS: Web of Science.

Source: Elaborated by the authors (2020).

After identifying the journals consisting of the sample, we proceeded with the document's dataset extraction. For this purpose, we considered all years up to 2020 in the time coverage, as we tried to retrieve as much data as possible. Regarding the document typology, we limited it to 'article', 'review', and 'conference paper' ('proceedings paper' in WoS) since these tend to be the potential typologies for citation analyses. The search strategy in both databases was conducted in February 2020. The search query performed in WoS was the following:

$I S=(1659-4142)$ OR $I S=(1683-8947)$ OR IS $=(0006-176 x)$ OR $I S=(1697-7904) O R I S=(1575-2437)$ OR $I S=(1659-3286)$ $O R I S=(1409-3049)$ OR IS $=(1575-5886)$ OR IS $=(0719-3661)$ OR IS $=(0719-367 x) O R I S=(1807-8893) O R I S=(1808-5245) O R$ $I S=(1696-2508)$ OR IS $=(2173-1071)$ OR IS $=(1413-9936) O R I S=(1981-5344)$ OR $I S=(1132-1873) O R I S=(1988-2858) O R$ $I S=(1135-3716) O R I S=(1386-6710) O R I S=(1699-2407) O R I S=(1888-0967) O R I S=(0187-358 X) O R I S=(0104-0146) O R$ $I S=(1809-4783) O R I S=(0210-0614)$ OR IS $=(1988-4621) O R I S=(1983-5213) O R I S=(0103-3786) O R I S=(1575-9733) O R$ $I S=(1133-3030) O R I S=(1134-2838)$ OR IS $=(2173-1241)$ OR IS=(1562-4730) OR IS=(2237-826x) OR IS=(2182-7974) OR IS=(0872-5632) OR IS=(2319-0698) OR IS=(1518-2924). Refined by: Publication range: up to 2020, and Document types: Articles or Review or Proceedings Papers.

While the query conducted in Scopus was the following:

SRCTITLE ("ciencias de la informacion") OR SRCTITLE ("ic revista cientifica de informacion y comunicacion") OR SRCTITLE ("boletim do arquivo da universidade de coimbra") OR SRCTITLE ("bibliotecas anales de investigacion") OR SRCTITLE ("cybermetrics") OR SRCTITLE ("encontros bibli") OR SRCTITLE ("anales de documentacion") OR SRCTITLE ("revista digital de biblioteconomia e ciencia da informacao") OR SRCTITLE ("informacion cultura y sociedad") OR SRCTITLE ("ibersid") OR SRCTITLE ("biblios") OR SRCTITLE ("scire") OR SRCTITLE ("cuadernos.info") OR SRCTITLE ("bid") OR SRCTITLE ("revista cubana de informacion en ciencias de la salud") OR SRCTITLE ("revista general de informacion y documentacion") OR SRCTITLE ("transinformacao") OR SRCTITLE ("revista interamericana de bibliotecologia") OR SRCTITLE ("revista espanola de documentacion cientifica") OR SRCTITLE ("investigacion bibliotecologica") OR SRCTITLE ("ciencia da informacao") OR 
SRCTITLE ("informacao e sociedade") OR SRCTITLE ("perspectivas em ciencia da informacao") OR SRCTITLE ("acimed") OR SRCTITLE ("profesional de la informacion") AND PUBYEAR < 2021 AND (LIMIT-TO (DOCTYPE, "ar") OR LIMIT-TO (DOCTYPE, "re") OR LIMIT-TO (DOCTYPE, " $c p^{\prime \prime)) .}$

Our search queries finally returned 8082 documents in WoS-CC, and 7169 in Scopus. It is worth mentioning some remarks about the journal selection process. The Biblios journal appears in Scopus as published by the University of Pittsburg, United States; however, we included it in our sample given its Peruvian origin. This journal is even indexed in the Scientific Electronic Library Online Peru collection. In 2013, the journal ACIMED changed its title to Revista Cubana de Información en Ciencias de la Salud; however, we merged both titles and processed it under the current one, as the new title did not represent a change in its scope (Comité Editorial, 2011). Arencibia-Jorge and Peralta-González (2020) recommend that, at the time to analyze the Library and Information Science (LIS) field, the dispersion of LIS journals indexed in other categories should be considered. In this matter, we noticed that some LIS-focused journals were not indexed in the Scopus LIS category; but we included them in our sample given their focus on information studies. This was the case of Ciencias de la Información (indexed in the 'Management Information Systems' category), and Informação \& Sociedade: Estudos (indexed in the'Communication', and 'Sociology and Political Science' categories). Finally, some Scopus journals indexed in the LIS category were indexed in WoS-CC under a different category; but given their approach to information studies, we considered them as well. This was the case of Boletim do Arquivo da Universidade de Coimbra (indexed in the'History' category), Cuadernos.info (indexed in the 'Communication' category), and IC Revista Científica de Información y Comunicación (indexed in the 'Communication' category).

The variables object of analysis in this study were the journals cited by the 33 source journals. Only LIS-oriented journals published by Ibero-American countries were processed, that is, we applied the same principle for the source journals identification. For this purpose, we found guidance from information resources like Latindex Directory, Dialnet, and INFOBILA since they index a large volume of LIS Ibero-American journals. In some cases, we visited the journal websites to confirm their LIS approach. The cited journals were subjected to a rigorous disambiguation process, through the generation of a thesaurus that made it possible to discard cited sources that did not represent our variable, as well as normalize the different variants of the same title. For those journals that suffered title changes, we processed the former title under the current one. Furthermore, journal self-citations were removed to rule out the effects of scholarly inbreeding, since authors show a strong preference for citing their national journals (Neal; Janulis; Collins, 2013). Through this procedure, we identified a total of 94 cited journals, the overlap of which is 71 .

To respond to RQ 1, related to intellectual structure, co-citation networks were generated by the "Visualization of Similarities (VOS)" method using the VOSviever software. The interpretation of the maps was carried out from the grouping of nodes in clusters, allowing to identify communities of journals with the greatest similarity (van Eck; Waltman, 2007; van Eck et al., 2010). The maps were made from those journals whose citation threshold was $\geq 5$.

To identify the core journals in the intellectual structure (RQ 2), a strategic diagram was generated. This is a two-dimensional graph initially proposed by Law et al. (1988) to examine the dynamics of a co-word analysis to identify local and global topics. Law et al. (1988) employed centrality and density measures by which topics with higher centrality were considered as more central, while topics with higher density were considered more mature. However, some adaptations to this diagram were made in this study since we considered Betweenness Centrality (BC) and citations at the node level as measures to build the diagram, and not the classic centrality and density measures at the cluster level, as used by Law et al. (1988). These measures were also employed by González-Valiente (2019) in a previous study.

Betweenness Centrality $(\mathrm{BC})$ is "[...] the degree to which a point falls on the shortest path between others and therefore has a potential for control of communication" (Freeman, 1977, p. 34). Thus, the higher the BC of a 
node, the higher its importance and potency (Freeman, 1977, 1978). This measure has been also considered as an indicator of interdisciplinarity of journals (Leydesdorff, 2007; Leydesdorff; Wagner; Bornmann, 2018). In this study, it was assumed as an indicator of 'importance', and we obtained it using the Gephi software. While the citations were considered as an 'impact' indicator, obtained through VOSviewer. The diagram was made up of four quadrants. Core journals were in quadrant 1, given that they had high levels of citation and betweenness. In quadrant 2, the journals under development were located, since they have high importance, but their impact is still low. Peripheral journals were in quadrant 3, given that their measures of both citations and betweenness were low. While in quadrant 4, were located journals whose impact was high, but their importance was low. In general, this strategic diagram helped to determine the position of the journals, not only from the citation impact perspective but also from the internal connections derived from the social network analysis perspective.

\section{Results}

\section{Intellectual structure of the Ibero-American research on LIS}

The co-citation map generated from the Scopus data is composed of 84 journals that are grouped into three clusters (Figure 1). The first cluster (red color) contains 36 journals, of which 32 are from Brazil, two from Portugal (Cadernos BAD, and Páginas a\&b), and one from Argentina (Palabras Clave, La Plata) and Uruguay (Informatio) in each case. This cluster reflects the context of publications in the Portuguese language. Among the titles with the highest Citations Weight (cw) are Ciência da Informação (cw: 1552), Perspectivas em Ciência da Informação (cw: 856), Datagramazero (cw: 455), Informação \& Sociedade: Estudos (cw: 388), and TransInformação (cw: 366). The second cluster (green color) displays the context of Spanish publications, given that, of the total of 25 journals grouped, 23

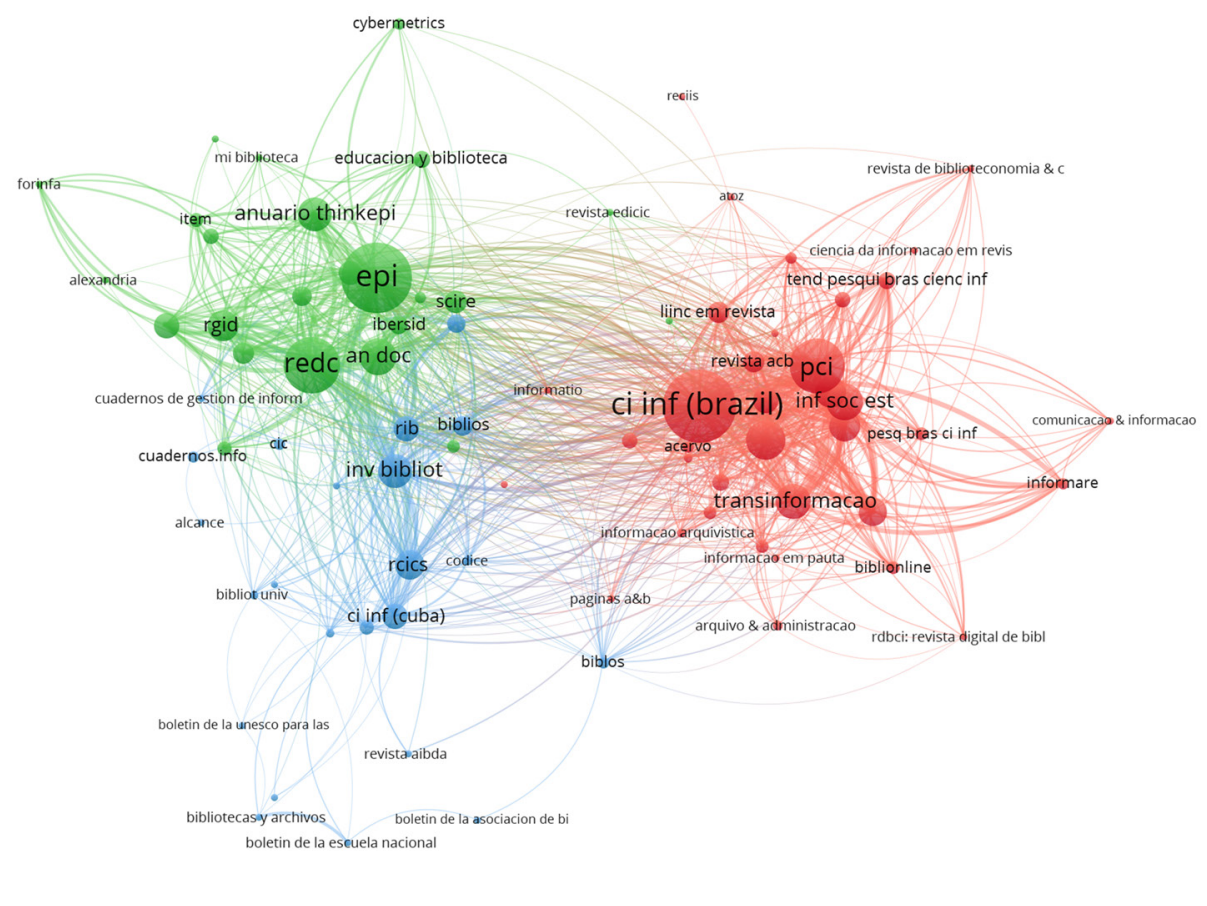

Figure 1 - Journal co-citation map based on Scopus data.

Source: Elaborated by the authors using VoSviewer (2020). 
are from Spain and only two from Brazil (Revista CRB-8 Digital, and Revista EDICIC). The most representative titles in this cluster are El Profesional de la Información (cw: 1409), Revista Española de Documentación Científica (cw: 918), Anales de Documentación (cw: 406), Anuario ThinkEPI (cw: 330), and Revista General de Información y Documentación (cw: 271).

The third cluster (blue color) groups the fewest number of journals, only 23. Most of these journals are published by countries located in Central America and the Caribbean, and South America (excluding Brazil). The journals in this cluster come from Cuba (5), Mexico (5), Costa Rica (2), Argentina (2), Colombia (2), Spain (2), Portugal (1), Venezuela (1), Peru (1), and Chile (1). In terms of citation, this cluster highlights Investigación Bibliotecológica (cw: 331), Revista Cubana de Información en Ciencias de la Salud (cw: 268), Revista Interamericana de Bibliotecología (cw: 199), Ciencias de la Información (cw: 189), and Biblios (cw: 113).

After the generation of the WoS co-citation map, significant shifts are detected compared to that of Scopus. This map is composed of 82 journals, which are grouped into two clusters only (Figure 2). In cluster one (in red), 40 journals from the Spanish-speaking countries are located, that is, from Spain, Latin America (discarding Brazil), and the Caribbean. Among the titles highlighted in this cluster we find: El Profesional de la Información (cw: 1571), Revista Española de Documentación Científica (cw: 959), Revista Cubana de Información en Ciencias de la Salud (cw: 461), Anales de Documentación (cw: 442), Anuario ThinkEPI (cw: 378), Investigación Bibliotecológica (cw: 350), and Revista General de Información y Documentación (cw: 329). While in cluster 2 (green cloror), made up of 34 journals, the same clustering pattern is evidenced as in the Scopus co-citation network, since only Brazilian and Portuguese journals are grouped here. In terms of citation, the same order of journals stands out in this cluster as in the Scopus map, that is: Ciência da Informação (cw: 2678), Perspectivas em Ciência da Informação (cw: 1083), Datagramazero (cw: 655), Informação \& Sociedade: Estudos (cw: 605), and TransInformação (cw: 463).

From the perspective of citation linkages, the Scopus map shows that the greatest link strengths (Is) between nodes occur between those that are part of the same cluster. For example, the most co-cited journals on the

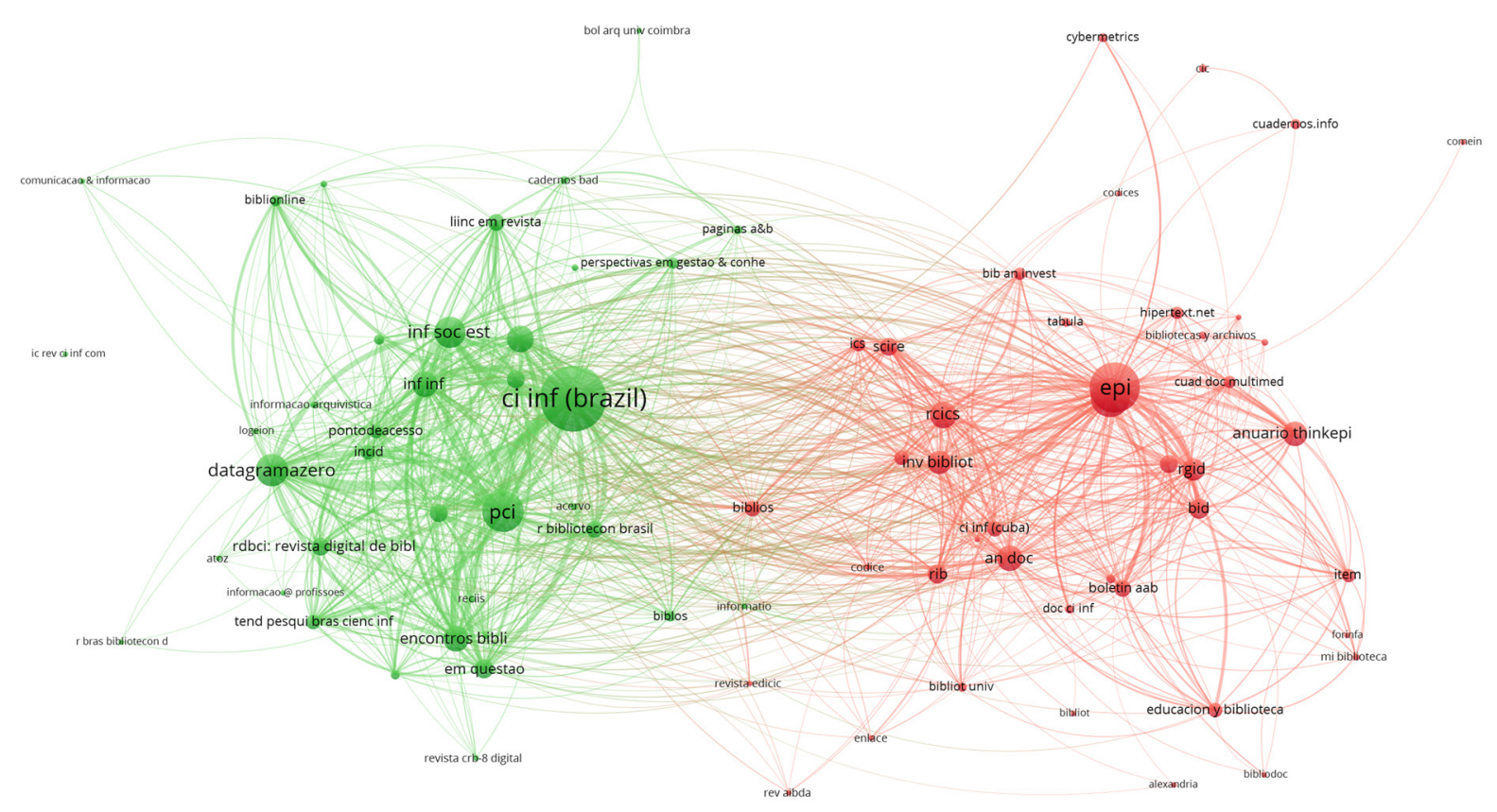

sviewer

Figure 2 - Journal co-citation map based on WoS data.

Source: Elaborated by the authors using VoSviewer (2020). 
entire map are those of the Brazilian community: Ciência da Informação-Perspectivas em Ciência da Informação (Is: 1577), Ciência da Informação-TransInformação (Is: 779), and Ciência da Informação-Datagramazero (Is: 692). In a second order are the journals of the Spanish community, standing out Revista Española de Documentación Científica-El Profesional de la Información (Is: 722), and El Profesional de la Información-Anuario ThinkEPI (Is: 346). In a third order, there are the relationships of the Latin American and the Caribbean (excluding Brazil) journals with those of Spain, such as: Investigación Bibliotecológica-El Profesional de la Información (Is: 181), Revista Cubana de Información en Ciencias de la Salud-Revista Española de Documentación Científica (Is: 167), e Investigación Bibliotecológica-Revista Española de Documentación Científica (Is: 150). The relations between the Spanish-speaking Latin American community and the Portuguese-speaking Latin American community are given, to a great extent, through the co-citation of El Profesional de la Información-Ciência da Informação (Is: 154), and Revista Española de Documentación Científica-Ciência da Informação (Is: 138). The least representative relationships are between the Spanish and Portuguese-speaking Latin communities. The most significant relationships between these two communities occur through Investigación Bibliotecológica-Ciência da Informação (Is: 126)

In the WoS map, the highest link strengths between nodes occur between titles that are also part of the same cluster; that is, the same pattern is evident as in the Scopus map. For example, in cluster 1 there are highly co-cited Revista Española de Documentación Científica and El Profesional de la Información (Is: 838), as well as El Profesional de Ia Información and Anuario ThinkEPI (Is: 444). With respect to cluster 2, the most co-cited journals are Perspectivas em Ciência da Informação and Ciência da Informação (Is: 2155), and Ciência da Informação and Datagramazero (Is: 1940). In this map, the greatest co-citation relationships between the Hispanic and Portuguese journals are through co-citation of Ciência da Informação with Revista Cubana de Información en Ciencias de la Salud (Is: 194), Investigación Bibliotecológica (Is: 188), Revista Española de Documentación Científica (Is: 187), and El Profesional de la Información (Is: 186).

\section{Core journals in the intellectual structure of the Ibero-American research on LIS}

Based on the citation and betweenness measures, the roles that journals play within the intellectual structure in the region have been identified. According to the strategic diagram generated with the Scopus data, there are only two core journals, due to their position in quadrant 1 (Figure 3). We are talking about the Spanish journal El Profesional de la Información and the Brazilian Ciencia da Informacao, two publications with the highest citation and BC measures. These have also been the most representative journals within the Spanish and Brazilian communities identified in the Scopus co-citation map (Figure 1).

In the second quadrant are located journals whose importance is high, but the impact of citations is low, such is the case of Perspectivas em Ciencia da Informacao, Datagramazero, Investigación Bibliotecológica, Ciencias de la Información, and e-Ciencias de la Información. It is noteworthy that Investigación Bibliotecológica appears as the most important journal since its BC measure is the highest in the entire co-citation map (BC: 160.3). We must also mention the almost central position of Perspectivas em Ciencia da Informacao, the fourth most-cited journal on the map, as well as Datagramazero, the fifth most-cited journal in this case, despite having ended its editorial activity in 2015.

In quadrant 3, considered as that of peripheral journals, most of the titles are. The journals whose citation and $\mathrm{BC}$ are low are located here, therefore, their impact and importance within the intellectual structure are poor. Although, in this quadrant, there are journals with a very notorious difference. For example, Revista Española de Documentación Científica reaches an almost central position in the diagram, note that it is the third most-cited journal (918 cites); but its betweenness is lower (BC: 69.3) compared to others whose citations are even lower. Something similar happens with highly cited journals; but the ones with unfavorable betweenness like Anales de Documentación (BC: 30.03), Informacao \& Sociedade: Estudos (BC: 57.31), Transinformacao (BC: 0), and Anuario 


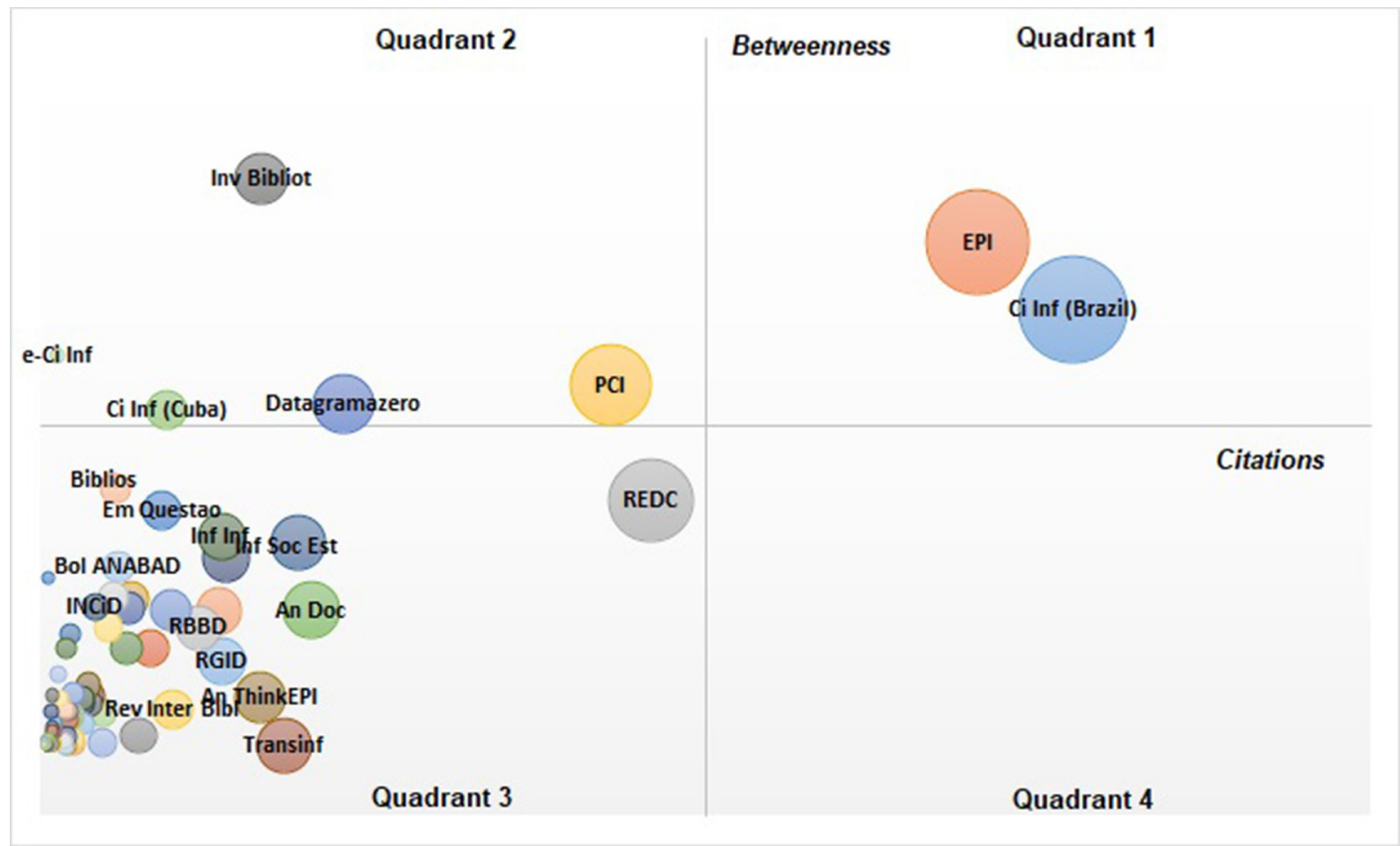

Figure 3 - Strategic diagram based on Scopus data. Source: Elaborated by the authors (2020).

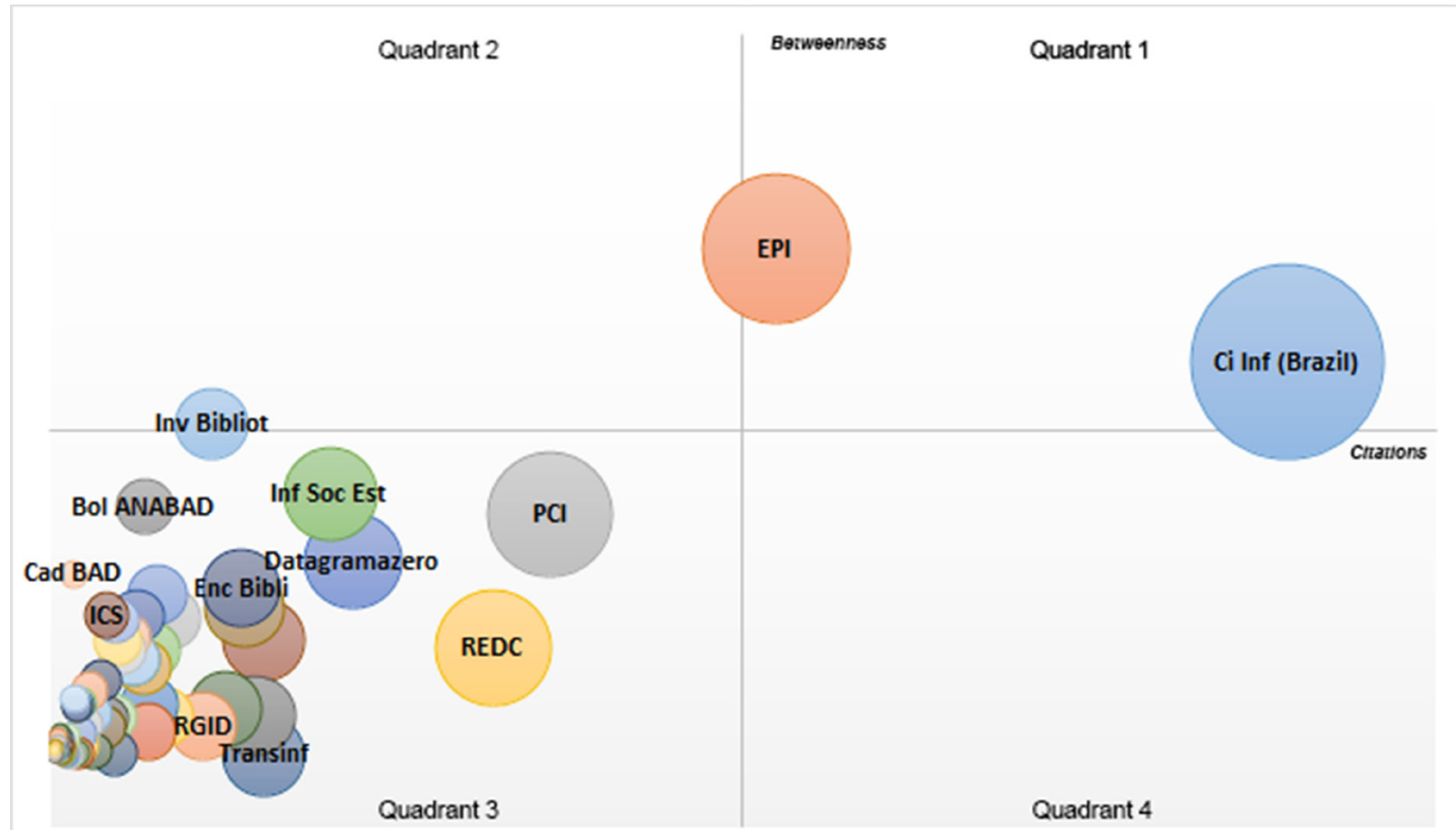

Figure 4 - Strategic diagram based on WoS data.

Source: Elaborated by the authors (2020). 
ThinkEPI (BC: 13.36). The most significant case is Trans/nformacao since it is the eighth most-cited journal in Scopus (366 cites), but its intermediation is 0 . Among the most critical journals in this quadrant are those that have ceased or have a thematic scope more limited to certain topics like archival science and library science. While, in the fourth quadrant, no journals appear; that is, there are no journals whose citations are considerably high and their betweenness low, compared to the rest.

The diagram generated from the WoS data shows that, as in Scopus, only Ciencia da Informacao and El Profesional de la Información are the most important and cited journals (Figure 4). On this occasion, only Investigación Bibliotecológica is part of quadrant 2, remaining as one of the most important journals in terms of betweenness. The rest of the journals are located in quadrant 3, as in the Scopus diagram. In this quadrant the same pattern is maintained as in the Scopus one, there is a notable imbalance in the journals located here, given the high citations of journals such as Perspectivas em Ciencia da Informacao (1083 cites), Revista Española de Documentación Científica (959 cites), Datagramazero (655 cites), Informacao \& Sociedade: Estudos (605 cites), and Transinformacao (463 cites); but their betweenness is still low to be in the first quadrant.

\section{Discussion and Conclusion}

Scientific journals are par excellence the formal channel for communicating science. They represent communities that can range from the most diverse to the most local when it comes to authors and thematic scope. Regarding the Ibero-American LIS journals, we count on many of them, especially those from Brazil and Spain. These journals concentrate a high volume of national research, something conditioned by their publishers since the vast majority are universities in which the LIS career is studied. Therefore, we assume that these publications contain a large part of the research produced by schools and university departments in the region.

Having mentioned the above, we take for granted the potential of these journals to identify the traits characterizing the Iberoamerican LIS research. From this premise, this study has been developed, which has not only sought a more comprehensive overview of the results provided by González-Valiente (2019) but also offers a comparative analysis from WoS and Scopus. On one hand, in the González-Valiente's article (2019), data from Scopus were used until 2017 and, from that date until 2021, titles such as Revista Interamericana de Bibliotecología, Bibliotecas. Anales de Investigación, Revista Digital de Biblioteconomia e Ciência da Informação, and Encontros Bibli were added to the database. On the other hand, although only five Ibero-American journals are indexed in the Social Science Citation Index (eg: El Profesional de la Información, Revista Española de Documentación Científica, Investigación Bibliotecológica, Transinformação, Informação \& Sociedade: Estudos), the database Emerging Sources Citation Index contains several Ibero-American journals, thus facilitating the study of another group of LIS journals in WoS. In some way, this coverage, and the additions of new titles in such databases have enriched our analysis.

It is a fact that different data offer different results, and the low coverage of Ibero-American LIS journals in WoS and Scopus - compared with the existing volume not yet indexed - provide partial results. That is why these findings are considered an 'approximation' to the intellectual structure of the discipline. On this basis, we evidence that despite defining a broader time coverage in Scopus compared to González-Valiente (2019), the current results do not show significant variations, given that:

- The intellectual structure is fragmented into the three previously identified communities: Spanish, Latin American Spanish-speaking, and Latin American Portuguese-speaking;

- El Profesional de la Información and Ciência da Informação still stand as the core journals;

- There is a group of non-source journals that stand out for their citation impact, such as Datagramazero, Anuario ThinkEPI, Informação \& Informação, RBBD. Revista Brasileira de Biblioteconomia e Documentação, and some others; 
- Most of the journals are peripheral due to the unfavorable number of citations compared to the two core journals mentioned above.

Now, what significant similarities and differences did the comparative perspective show between Scopus and WoS? To a significant extent, we identified more similarities than differences, standing out:

- Only El Profesional de la Información and Ciencia da Informação stand as the core journals in the discipline, as their citations and betweenness measures are the highest in the co-citation maps;

- The high citation levels of El Profesional de la Información, and Ciencia da Informação place the remaining journals at a total disadvantage, taking them to a peripheral position (quadrants 3 ) in both strategic diagrams (Figures 3 and 4);

- Even though most of the journals are in quadrant 3, there is a group of journals that move towards a gradual core status due to their high citations, such as Revista Española de Documentación Científica, Perspectivas em Ciencia da Informação, Investigación Bibliotecológica, Informação \& Sociedade: Estudos, TransInformação, Revista Cubana de Información en Ciencias de la Salud, and some others;

- The journals with the lowest citation and betweenness measures are mainly those that are no longer active (eg: Cybermetrics, Revista EDICIC, Alexandria, Forinf@), or whose scope is more limited to topics such as library science, and archival science (Bibliotecas, Mi Biblioteca, Arquivistica.net, Llígall, Informação Arquivistica, Arquivo \&Administração);

Among the main differences detected from both databases, we mention that:

- Although the Scopus results evidenced three journal communities (the Spanish, the Brazilian, and the Spanish-speaking Latin American); the WoS results only displayed two communities, one referring to Spanish-speaking journals (Spain, Latin America, and the Caribbean) and the other one to the Portuguese-speaking journals (Brazil, and Portugal).

- The Scopus results show a greater number of journals whose high betweenness measures rank them to be in quadrant 2, that is, journals that are important due to their connecting role, but with a lower citation impact. This means that journals in the bi-dimensional Scopus diagram are in three of the four quadrants. Whereas, from the WoS data, the journals are usually located in two quadrants, the core (quadrant 1) and the peripheral (quadrant 3).

Through the results obtained, we confirm that the intellectual structure of the Iberoamerican LIS research - seen from the journal citation relations - is fragmented by what could be geographical contexts and 'apparent' linguistic factors. We use the term 'apparent' because, from the analysis employed here, it cannot be confirmed that language is the main factor in this subdivision of communities. From the perspective of citation behavior, it is a fact that authors tend to cite national journals (Lancaster; Kim Lee; Diluvio, 1990), articles whose theoretical contexts are similar (Repiso; Moreno-Delgado; Aguaded, 2020), as well as their language (Bookstein; itzhaki, 1999). However, the way the intellectual structure is fragmented is a phenomenon that requires a deeper insight, since many epistemic factors might influence it. It must be taken into consideration that we have in the region a variety of schools of thought (Ríos Ortega, 2008), denominations of academic training (Munera Torres, 2018), and areas of knowledge supporting the LIS field (Munera Torres, 2016).

As in the study by Herrero-Solana and Liberatore (2008), the number of journals with the highest levels of citations is still limited in our geographical context. The significant difference between El Profesional de la Información and Ciência da Informação compared with the rest of the journals means that the others are in the peripheral quadrant. In other words, only a small number of journals have a strong influence on the discipline. However, this should not be interpreted as 'higher or lower quality journals', since all journals do not share equally the same historical tradition, author communities, thematic openness, financial support, or even editorial interest. 
We believe that studying the intellectual structure of the Iberoamerica LIS research from a different perspective than journal citation networks would aid in better identifying the most interesting traits of the LIS field in the region. Further studies might employ other bibliometric indicators to detect if the present fragmentation in the intellectual structure is also visible. All this might help us to better define the epistemic frameworks towards the construction of an 'Ibero-American informational thinking'.

\section{References}

Abadal, E.; Guallar, J. La investigación en Documentación en España: diagnóstico 2020. Profesional de la Información, v. 29, n. 4, p. e290444, 2020. Doi: https://doi.org/10.3145/epi.2020. jul. 44

Amaro-Ares, A.; Vega-Almeida, R. L.; Arencibia-Jorge, R. El impacto de las publicaciones seriadas y su efecto sobre la producción científica cubana sobre Bibliotecología y Ciencias de la Información. Bibliotecas: Anales de Investigación, v. 14, n. 1, p. 34-50, 2018.

Araújo, C. A. Á. Existe um pensamento información al iberoamericano? Logeion: Filosofia da Informação, v. 4, n. 2, p. 3155, 2018a. Doi: https://doi.org/10.21728/logeion.2018v4n2. p31-55

Araújo, C. A. Á. Em defesa de um pensamento información al ibero-americano. In: XI Encuentro de la Asociación de Educación e Investigación en Ciencia de la Información de Iberoamérica y el Caribe, 2018, Medellín. Actas [...]. Medellín: Universidad de Antioquía, 2018b.

Araújo, C. A. Á.; González-Valiente, C. L. Hacia un pensamiento información al iberoamericano. Bibliotecas: Anales de Investigación, v. 15, n. 2, p. 137-139, 2019.

Araújo, C. A. Á.; Valentim, M. L. P. A Ciência da Informação no Brasil: mapeamento da pesquisa e cenário institucional. Bibliotecas. Anales de Investigación, v. 15, n. 2, p. 232-259, 2019.

Arencibia-Jorge, R.; Peralta-González, M. J. Recommendations on the use of Scopus for the study of Information Sciences in Latin America. Iberoamerican Journal of Science Measurement and Communication, v. 1, n. 1, p. 8, 2020. Doi: https://doi. org/10.47909/ijsmc.07

Bookstein, A.; Yitzhaki, M. Own-language preference: a new measure of "relative language self-citation". Scientometrics, v. 46, n. 2, p. 337-348, 1999. Doi: https://doi.org/10.1007/ bf02464782

Borges, M. M.; Freitas, M. C. V. D.; Oliveira, S. R. D. A Ciência da Informação em Portugal nas primeiras décadas do século XXI: uma abordagem preliminar para uma cartografia iberoamericana. Bibliotecas: Anales de Investigación, v. 2, n. 15, p. 260-292, 2019.

Comité Editorial. Revista Cubana de Información en Ciencias de la Salud: hacia una etapa superior. ACIMED, v. 22, n. 1, p. 1-2, 2011. Available at: http://scielo.sld.cu/scielo.php?script=sci_ arttext\&pid=S1024-94352011000100001\&lng=es\&nrm=iso. Accessed on: 27 Apr. 2021.

Corda, M. C.; Liberatore, G. Research on library and information science in Argentina during the first decades of the XXI century. Iberoamerican Journal of Science Measurement and Communication; v. 1, n. 2, p. 1-19, 2021. Doi: https://doi. org/10.47909/ijsmc.44

Freeman, L. C. A set of measures of centrality based on betweenness. Sociometry, v. 40, n. 1, p. 35-41, 1977. Doi: https://doi.org/10.2307/3033543

Freeman, L. C. Centrality in social networks conceptual clarification. Social Networks, v. 1, n. 3, p. 215-239, 1978. Doi: http://doi.org/10.1016/0378-8733(78)90021-7

González-Valiente, C. L. Redes de citación de revistas iberoamericanas de Bibliotecología y Ciencia de la Información en Scopus. Bibliotecas: Anales de Investigación, v. 19, n. 1, p. 83-98, 2019.

Gorbea-Portal, S.; Suárez-Balseiro, C. A. Análisis de la influencia y el impacto entre revistas periféricas no incluidas en el Science Citation Index. Revista Interamericana de Bibliotecología, v. 30, n. 2, p. 47-70, 2007.

Gutiérrez, J. J. P. La investigación en Biblioteconomía y Documentación en Iberoamérica. Análisis de la internacionalización de las revistas con impacto en Scopus. In: M. T. Fernández Bajón; I. Villaseñor Rodríguez (ed.). Retos y tendencias de la investigación Hispano-Mexicana en Ciencias de la Información y de la Documentación. Madrid: FADOC, 2020. p. 331-348.

Herrera-Miranda, I.; Arenas, J. L.; Gómez-Hernández, J. A. Publicaciones periódicas en biblioteconomía, bibliotecología, ciencias de la información y documentación en México: tendencias temáticas, productividad y redes de coautoría: 1956-2006. Revista Interamericana de Bibliotecología, v. 36, n. 2, p. 97-108, 2013.

Herrero-Solana, V. H.; Liberatore, G. Visibilidad internacional de las revistas iberoamericanas de Bibliotecología y Documentación. Revista Española de Documentación Científica, v. 31, n. 2, p. 230-239, 2008. Doi: https://doi.org/10.3989/redc.2008.v31.i2.426

Jaramillo, O.; Morillo, J. P. La investigación en Archivística, Bibliotecología y Ciencia de la Información en Colombia: 2007-2017. Bibliotecas: Anales de Investigación, v. 15, n. 2, p. 141-158, 2019.

Lancaster, F. W.; Kim Lee, S. Y.; Diluvio, C. Does place of publication influence citation behavior? Scientometrics, v. 19, n. 3-4, p. 239-244, 1990. Doi: https://doi.org/10.1007/ BF02095350

Law, J. et al. Policy and the mapping of scientific change: a co-word analysis of research into environmental acidification. Scientometrics, v. 14, n. 3-4, p. 251-264, 1988. Doi: https://doi. org/10.1007/bf02020078

Leydesdorff, L. "Betweenness centrality" as an indicator of the "interdisciplinarity" of scientific journals. Journal of the 
American Society for Information Science and Technology, v. 58, n. 9, p. 1303-1309, 2007. Doi: https://doi.org/10.1002/ asi.20614

Leydesdorff, L.; Wagner, C. S.; Bornmann, L. Betweenness and diversity in journal citation networks as measures of interdisciplinarity-A tribute to Eugene Garfield. Scientometrics, v. 114, n. 2, p. 567-592, 2018. Doi: https://doi.org/10.1007/ s11192-017-2528-2

Liberatore, G.; Herrero-Solana, V. Caracterización temática de la investigación en Ciencia de la Información en Brasil en el período 2000-2009. Transinformação, v. 25, n. 3, p. 225-235, 2013. Doi: https://doi.org/10.1590/S010337862013000300005

Morán-Reyes, A. Research trends in Information Sciences in Mexico: historical and bibliometric notes on doctoral theses from the National Autonomous University of Mexico (2002-2021). Iberoamerican Journal of Science Measurement and Communication, v. 1, n. 2, p. 1-18, 2021. Doi: https://doi. org/10.47909/ijsmc.46

Mugica, M. M. M.; Columbié, R. L.; Salomón, Y.P. La investigación cubana en Ciencias de la Información: el caso de los estudios de postgrado (2008-2018). Bibliotecas: Anales de Investigación, v. 15, n. 2, p. 212-231, 2019.

Munera Torres, M. T. Algunas tendencias de la formación bibliotecológica en América Latina. Investigación Bibliotecológica, v. 32, n. 74, p. 101-122, 2018. Doi: https://doi.org/10.22201/ iibi.24488321xe.2018.74.57912

Munera Torres, M. T. La terminología de la bibliotecología en América Latina: un estudio comparativo. 2016. Tesis (Doctorado en Información y Documentación) - Universidad de Zaragoza, Zaragoza, 2016.

Neal, J. W.; Janulis, P.; Collins, C. Is community psychology "too insular"? a network analysis of journal citations. Journal of Community Psychology, v. 41, n. 5, p. 549-564, 2013. Doi: https://doi.org/10.1002/jcop.21556
Oliveira, S. R. et al. Thematic Identification of "Little Science": trends in Portuguese IS\&LS Literature by ControlledVocabulary and Co-Word Analysis. Qualitative and Quantitative Methods in Libraries, v. 4, n. 2, p. 421-432, 2017.

Repiso, R.; Moreno-Delgado, A.; Aguaded, I. Factors affecting the frequency of citation of an article. Iberoamerican Journal of Science Measurement and Communication, v. 1, n. 1, p. 7, 2020. Doi: https://doi.org/10.47909/ijsmc.08

Ríos Ortega, J. Didáctica de la Bibliotecología: teoría y principios desde la enseñanza de la ciencia. México: UNAM, 2008.

Sabelli, M. La Ciencia de la Información en Uruguay (2013-2017): líneas de investigación y producción académica. Bibliotecas: Anales de Investigación, v. 15, n. 2, p. 179, 2019.

Sánchez-Perdomo, R. et al. Revisión bibliométrica de las Ciencias de la Información en América Latina y el Caribe. Investigación Bibliotecológica, v. 31, p. 79-100, 2017. Doi: http:// doi.org/10.22201/iibi.24488321xe.2017.nesp1.57886

van Eck, N. J. et al. A comparison of two techniques for bibliometric mapping: multidimensional scaling and VOS. Journal of the American Society for Information Science and Technology, v. 61, n. 12, p. 2405-2416, 2010. Doi: https://doi. org/10.1002/asi.21421

van Eck, N. J.; Waltman, L. VOS: a new method for visualizing similarities between objects. In: Decker, R.; Lenz, H. J. (ed.). Advances in data analysis. Berlin: Springer, 2007. p. 299-306. Doi: https://doi.org/10.1007/978-3-540-70981-7_34

Vega-Almeida, R. L.; Arencibia-Jorge, R. Research on Information Sciences in Cuba: flows of knowledge during the period 2005-2019. Iberoamerican Journal of Science Measurement and Communication, v. 1, n. 2, p. 1-28, 2021. Doi: https://doi.org/10.47909/ijsmc.50

Vergara-Vera, P. et al. Análisis multivariado de la producción científica iberoamericana indexada en WOS en Bibliotecología y Ciencias de la Información. Trilogía:Ciencia-Tecnología-Sociedad, v. 33, n. 44, p. 62-78, 2020. 